\title{
"The impact of human resource development practices on employee engagement and performance in Jordanian family restaurants"
}

\begin{tabular}{|c|c|}
\hline \multirow{3}{*}{ AUTHORS } & Amani Abu Rumman iD https://orcid.org/0000-0002-6557-7463 \\
\hline & Lina Al-Abbadi ID https://orcid.org/0000-0003-2992-2642 \\
\hline & Rawan Alshawabkeh iD https://orcid.org/0000-0003-2451-5474 \\
\hline ARTICLE INFO & $\begin{array}{l}\text { Amani Abu Rumman, Lina Al-Abbadi and Rawan Alshawabkeh (2020). The } \\
\text { impact of human resource development practices on employee engagement and } \\
\text { performance in Jordanian family restaurants. Problems and Perspectives in } \\
\text { Management, 18(1), 130-140. doi:10.21511/ppm.18(1).2020.12 }\end{array}$ \\
\hline DOI & http://dx.doi.org/10.21511/ppm.18(1).2020.12 \\
\hline RELEASED ON & Thursday, 20 February 2020 \\
\hline RECEIVED ON & Thursday, 07 November 2019 \\
\hline ACCEPTED ON & Tuesday, 28 January 2020 \\
\hline & $(\mathrm{cc})$ EY \\
\hline LICENSE & $\begin{array}{l}\text { This work is licensed under a Creative Commons Attribution } 4.0 \text { International } \\
\text { License }\end{array}$ \\
\hline JOURNAL & "Problems and Perspectives in Management" \\
\hline ISSN PRINT & $1727-7051$ \\
\hline ISSN ONLINE & $1810-5467$ \\
\hline PUBLISHER & LLC "Consulting Publishing Company "Business Perspectives" \\
\hline FOUNDER & LLC “Consulting Publishing Company "Business Perspectives" \\
\hline & $\begin{array}{l}\text { ニニ- } \\
\text { ニニ- }\end{array}$ \\
\hline NUMBER OF REFERENCES & NUMBER OF FIGURES \\
\hline 52 & 3 \\
\hline
\end{tabular}

(c) The author(s) 2023. This publication is an open access article. 


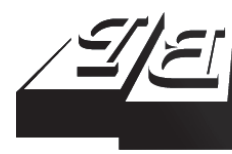

\section{BUSINESS PERSPECTIVES}

$\odot$

LLC "CPC "Business Perspectives"

Hryhorii Skovoroda lane, 10,

Sumy, 40022, Ukraine

www.businessperspectives.org

Received on: $7^{\text {th }}$ of November, 2019 Accepted on: $28^{\text {th }}$ of January, 2020 Published on: $20^{\text {th }}$ of February, 2020

(C) Amani Abu Rumman, Lina AlAbbadi, Rawan Alshawabkeh, 2020

Amani Abu Rumman, Ph.D., Assistant Professor, Business Administration Department, Business School, Al-

Ahliyya Amman University, Amman, Jordan.

Lina Al-Abbadi, Ph.D., Assistant Professor, Business Administration Department, Business School, AlAhliyya Amman University, Amman, Jordan.

Rawan Alshawabkeh, Ph.D., Assistant Professor, Business Administration Department, Business School, AlAhliyya Amman University, Amman, Jordan.
Amani Abu Rumman (Jordan), Lina Al-Abbadi (Jordan),

Rawan Alshawabkeh (Jordan)

\section{THE IMPACT OF HUMAN RESOURCE DEVELOPMENT PRACTICES ON EMPLOYEE ENGAGEMENT AND PERFORMANCE IN JORDANIAN FAMILY RESTAURANTS}

\begin{abstract}
Given the organizational positive outcomes of human resource development (HRD) practices like organizational effectiveness, sustainable competitive advantage, and organizational commitment, the current study was designed to detect the impact of HRD practices (employee training, employee empowerment, employee promotion) as independent variables on employee engagement and employee performance as dependent variables and to notify those who are interested. A quantitative descriptive-analytical method was adopted for the current research paper. Data were collected conveniently via a questionnaire from employees of family restaurants. Usable responses were analyzed using IBM SPSS and AMOS on the strength of structural equation modeling (SEM).

The current data identified employee training, employee empowerment, and employee promotion as key predictors of both employee engagement and employee performance. Employee empowerment has the highest impact on employee engagement, followed by employee promotion, while employee training has the highest effect on employee performance. Furthermore, employee engagement is positively related to employee performance.
\end{abstract}

\section{Keywords}

HRD practices, employee engagement, employee performance, family restaurants

\section{JEL Classification $\quad$ M50, M51, M53}

\section{INTRODUCTION}

Organizations are required to design and implement HRD practices to ensure numerous positive organizational outcomes in terms of organizational performance, organizational effectiveness, enhancing market performance, sustainable competitive advantage, and organizational commitment. Specifically, employee promotion, employee empowerment, employee motivation, employee training, and development practices positively affect organizational commitment, employee competencies, and job satisfaction (Mugizi, 2019; Al-Hawary et al., 2013; Potnuru, Sahoo, \& Sharma, 2019; Paposa \& Kumar, 2019). Therefore, organizations should develop their human resources to be ready for present and future work requirements.

Given the importance of HRD practices in improving the performance, both at individual and organizational levels, researchers have been interested in exploring the effects of these practices on, for instance, employee engagement and employee performance. However, studies on this issue using the samples from the restaurant sector are 
still few, especially since restaurants rarely train the staff because they recruit and attract people with sufficient skills and experience. Therefore, the present study is of interest and provides additional scientific knowledge by demonstrating human resource development practices in restaurants and their significance in improving the employee engagement and performance, which, in turn, affects the overall success of the organization.

\section{LITERATURE REVIEW}

\subsection{HRD definition and practices}

HRD practices had been defined as systematic and planned activities outlined by organizations to enable the employees to acquire prerequisite skills for coming across present and future job demands (Mugizi, 2019). According to Potnuru, Sahoo, and Sharma (2019), HRD is one of the sources through which organizations can improve the competencies of their employees. Although all human resource practices are important for the development of human resources, some of these practices are primarily directed towards employee development, such as employee training and promotion. The following paragraphs review the dimensions of HRD practices contained in the literature and the dimensions used in the present research paper.

HRD practices were conceptualized by researchers using different practices. Examples of these practices in the literature are summarized in Table 1. Fletcher (2019) examined the relationship between employee perceived opportunities for development and job engagement through meaningfulness as a mediating variable and perceived line manager relations as a moderator variable. The author measured perceived opportunities for development using formal opportunities like second men and informal such as employee recruitment as a leader for new projects. Mugizi (2019) used three practices of HRD, which were employee performance appraisal, employee training, and employee promotion. Potnuru, Sahoo, and Sharma
(2019) examined the impact of team building and employee empowerment as key dimensions of human resource development on employee competencies, as well as the moderating effect exerted by organizational learning culture on the relationship between these two constructs. Jain (2014) carried out a study to explore the effect of employee performance appraisal as a major practice of employee on employee efficiency, organizational efficiency, and productivity. Amirthaiyan and Victor (2016) mentioned five practices of employee development, which were performance appraisal, employee training and development, work-life quality, welfare measure, and employee engagement. Archana and Krishna (2016) considered employce training as a key pillar of HRD practices.

Three HRD practices were chosen for the current study: employee training, employee empowerment, and employee promotion. Training has been defined as an elevator of employee performance in accordance with his or her enhanced skills (Tahsildari \& Shahnaei, 2015; Hidayat \& Budiatma, 2018). Employee empowerment is another elevator of employee performance because it improves employee motivation and belonging to increase his or her engagement and commitment (Sweis, Al-Mansour, Tarawneh, \& Al-Dweik, 2013). According to Al-Hawary et al. (2013), employee empowerment can be understood by allowing the employee to solve problems based on his or her judgment, accepting his or her initiatives, and the management's confidence in the employee's judgments. Finally, employee promotion refers to the elevation of the employee from his current job po-

Table 1. Examples of HRD practices in the literature

\begin{tabular}{|c|c|}
\hline HRD practices & Authors \\
\hline Performance appraisal & $\begin{array}{l}\text { Jain (2014), Amirthaiyan and Victor (2016), Mugizi (2019), Potnuru, Sahoo, and Sharma (2019), Paposa and } \\
\text { Kumar (2019) }\end{array}$ \\
\hline Employee training & $\begin{array}{l}\text { Mugizi (2019), Potnuru, Sahoo, and Sharma (2019), Paposa and Kumar (2019), E. Smith, Callan, Tuck, and A. } \\
\text { Smith (2019) }\end{array}$ \\
\hline Team building & Potnuru, Sahoo, and Sharma (2019), Paposa and Kumar (2019) \\
\hline Employee empowerment & Mugizi (2019), Potnuru, Sahoo, and Sharma (2019), Paposa and Kumar (2019) \\
\hline Employee promotion & Fletcher (2019), Mugizi (2019), Potnuru, Sahoo, and Sharma (2019), Paposa and Kumar (2019) \\
\hline
\end{tabular}


sition to a higher job position than on the career ladder (Ali \& Ahmad, 2017). Njagi (2012) identified three key characteristics of employee promotion, which are getting a better job position, a higher salary, plus extra responsibilities. Accordingly, the development of human resources involves preparing the employee cognitively, behaviorally, and emotionally and ensuring his commitment to assume new responsibilities after promotion.

\subsection{HRD practices outcomes}

Outcomes of HRD practices can be well understood through social exchange theory. Fletcher (2019) highlights the importance of social exchange theory, which postulates that the employees and the management of an organization exchange tangible or intangible resources. Tangible resources such as cash incentives or intangible resources like employee recognition result in more positive outcomes from employee engagement. Numerous positive outcomes of HRD practices had been cited in the literature. The following paragraphs show the development of hypotheses related to HRD practices and some of these positive outcomes.

\subsubsection{HRD practices and employee engagement}

HRD practices aimed at improving the skills and competencies of employees are expected to lead to improved employee engagement. The term engagement was first defined by Kahn (1990) when he defined the term as a state in which an employee dedicated himself or herself to work physically, cognitively, and emotionally. Jose and Mampilly (2012) provided theoretical support on the positive effect of HR practices on employee engagement. The following is a presentation of some of the findings of some relevant studies on the relationship between HRD practices and employee engagement.

B. Shuck, Twyford, Reio Jr, and A. Shuck (2014) found that HRD practices had a significant negative effect on employee turnover intention when the relationship between these variables was mediated by employee engagement, as measured by cognitive, emotional, and behavioral engagement. Fletcher (2019) detected a positive relationship between employee perceived formal and informal opportunities for development and his or her engagement level. Sattar, Ahmad, and Hassan (2015) pointed out that employee engagement partially mediated the impact of HR practices, i.e., employee training, employee reward, and employee empowerment, on employee satisfaction and performance. Based on the abovementioned literature, the following hypotheses were assumed:

H1: Employee training significantly anticipates the employee engagement.

H2: Employee empowerment significantly anticipates the employee engagement.

H3: Employee promotion significantly anticipates the employee engagement.

\subsubsection{HRD practices and employee performance}

It makes sense to assume that there is a positive correlation between employee training and work performance because the purpose of training is to improve employee skills and teach him or her how to apply these skills at work. Several previous studies have confirmed this assumption. The study of Busari, Mughal, Khan, Rasool, \& Kiyaniet (2017) detected a positive effect of employee training and development on employee performance. Employee high degree of performance reported in Asfaw, Argaw, and Bayissa (2015) was due to employee training and development.

Yamoah (2014) concluded that the positive effect of human resource capacity, when conceptualized in terms of employee training and employee empowerment had been well documented in the literature. Mozael (2015) discussed the impact of training and development programs on employee performance and concluded that the positive impact of training lies in the skills and competencies acquired by the employee, which in turn leads to improving his or her ability to carry out work tasks efficiently. Using a sample of higher education system employees in the Kingdom of Saudi Arabia, Alshery, Ahmad, and Al-Swidi (2015) asserted the positive influence of employee training on employee performance. Consequently, the following hypotheses were suggested: 
H4: Employee training significantly anticipates the employee performance.

H5: Employee empowerment significantly anticipates the employee performance.

H6: Employee promotion significantly anticipates the employee performance.

H7: Employee engagement significantly anticipates the employee performance.

\section{METHOD}

\subsection{Research sample and data collection}

The population of the current study covers the employees of family restaurants in the capital city of Jordan (Amman). Based on the descriptive-analytical method, questionnaires were distributed to a convenience sample of employees. The total number of valid questionnaires for data analysis was 213 questionnaires. The rationale why this method of sampling was used is the availability of employees at data collection time (Etikan, Musa, \& Alkassim, 2016).

\subsection{Research instruments}

A questionnaire was developed to collect the data required for the current study with reference to the literature (Chen, Tsui, \& Farh, 2002; Schaufeli, Salanova, González-Romá, \& Bakker, 2002; Saks, 2006; Al-Hawary et al., 2013; Aguta \& Balcioglu, 2015; Asfaw, Argaw, \& Bayissa, 2015; Busari et al. 2017; Mugizi, 2019; Potnuru, Sahoo, \& Sharma, 2019). It contained five variables: employee training, employee empowerment, employee promotion as independent variables, as well as employee engagement and employee performance as dependent variables. The initial version included thirty-five items, so that each variable was measured using five items. After presenting the questionnaire to six experts from academics in three universities, twelve items were eliminated for their inadequacy to measure the variable. Table 2 presents the final version of the questionnaire after conducting the exploratory factor analysis (EFA), as will be shown later, in which reliability and validity were assured.

Table 2. Questionnaire items

\begin{tabular}{|c|c|c|c|}
\hline Practices & Code & Items & Authors \\
\hline \multirow{4}{*}{ Employee training } & TRG1 & My training needs are determined based on my performance & \multirow{4}{*}{$\begin{array}{l}\text { Al-Hawary et al. (2013), } \\
\text { Asfaw, Argaw, and Bayissa } \\
\text { (2015), Mugizi (2019) }\end{array}$} \\
\hline & TRG2 & My organization offers me the opportunity to train & \\
\hline & TRG3 & The organization supports me to participate in workshops & \\
\hline & TRG4 & The training I receive is appropriate for me & \\
\hline \multirow{4}{*}{$\begin{array}{l}\text { Employee } \\
\text { empowerment }\end{array}$} & EMP1 & Employee participation in planning of daily activities & \multirow{4}{*}{$\begin{array}{l}\text { Al-Hawary et al. (2013), } \\
\text { Potnuru, Sahoo, and Sharma } \\
(2019)\end{array}$} \\
\hline & EMP2 & Employee involvement in decision-making process & \\
\hline & EMP3 & Employee good access to information and resources & \\
\hline & EMP4 & Employee freedom to express their viewpoints & \\
\hline \multirow{4}{*}{$\begin{array}{l}\text { Employee } \\
\text { promotion }\end{array}$} & PRO1 & I understand the advancement requirements for my job & \multirow{4}{*}{$\begin{array}{l}\text { Aguta and Balcioglu (2015), } \\
\text { Busari et al. (2017), Mugizi } \\
\text { (2019) }\end{array}$} \\
\hline & $\mathrm{PRO} 2$ & Merit is the foundation of promotion in this organization & \\
\hline & $\mathrm{PRO} 3$ & Promotion opportunities are available to me & \\
\hline & $\mathrm{PRO} 4$ & The organization's promotion policy is clear for me & \\
\hline \multirow{4}{*}{$\begin{array}{l}\text { Employee } \\
\text { engagement }\end{array}$} & ENG1 & I am engaged with my work so that I do not feel the time & \multirow{4}{*}{ Schaufeli (2002), Saks (2006) } \\
\hline & ENG2 & My work takes all my time & \\
\hline & ENG3 & Part of my life is that I am a member of this organization & \\
\hline & ENG4 & I can work for long hours & \\
\hline \multirow{4}{*}{$\begin{array}{l}\text { Employee } \\
\text { performance }\end{array}$} & PER1 & I meet my desired performance expectations & \multirow{4}{*}{$\begin{array}{l}\text { Chen, Tsui, and Farh (2002), } \\
\text { Peterson, Luthans, Avolio, } \\
\text { Walumbwa, and Zhang } \\
\text { (2011) }\end{array}$} \\
\hline & PER2 & I do my job efficiently & \\
\hline & PER3 & I can take my job responsibilities & \\
\hline & PER4 & I finish my work tasks on time & \\
\hline
\end{tabular}




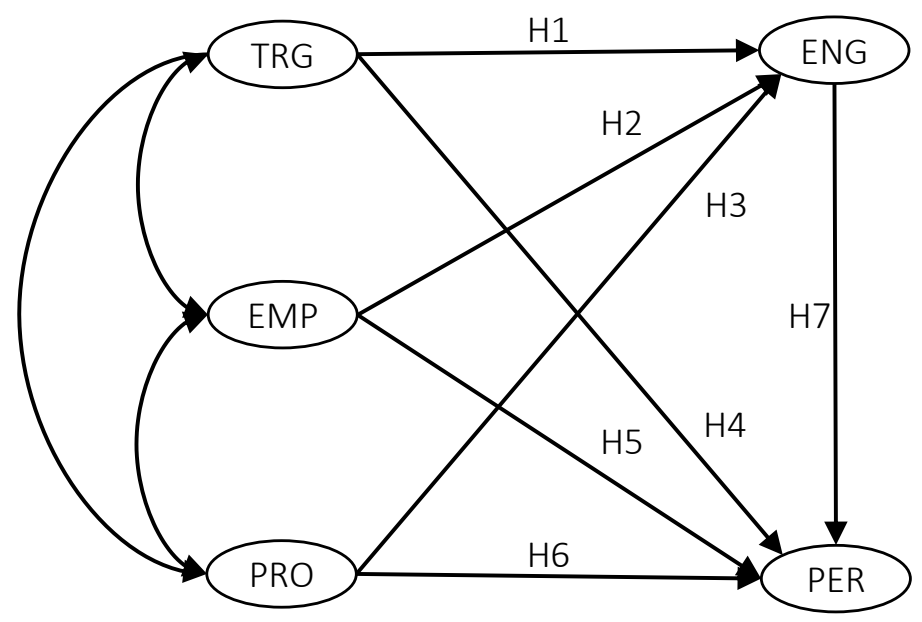

Figure 1. Research conceptual model

\subsection{Research model}

Figure 1 exhibits the conceptual model of this study. It incorporates five latent variables: employee training (TRG), employee empowerment (EMP), employee promotion (PRO), employee engagement (ENG), and employee performance (PER). The model was structured according to seven hypotheses, in which HRD practices were assumed to have effects on HRD outcomes. HRD dimensions TRG, EMP, and PRO were hypothesized to exert significant impacts on both employee engagement and employee performance. Moreover, employee engagement was postulated to predict employee performance.

\section{RESULTS}

\subsection{Reliability and validity}

Exploratory factor analysis (EFA) was used to extract the standardized factor loadings (SFL) and to compute the average variance extracted (AVE) and composite reliability (CR). EFA was conducted using IBM SPSS ${ }^{\circ}$ version 24.0 via dimension reduction command, in which components were principally extracted, based on a fixed number of factors and rotated by varimax method suppressing small coefficients below the absolute value of 0.4 .

Composite reliability (CR) and Cronbach's alpha coefficients were used to evaluate reliability with values of 0.7 or greater (Al-Hawary \& Al-
Smeran, 2016). According to Bacon, Sauer, and Young (1995), both composite reliability and Cronbach's alpha are common measures used by researchers in structural equation modeling (SEM). Convergent validity was assessed based on the rule that removes all indicators with a non-significant loading (Raubenheimer, 2004). Therefore, factor loadings greater than 0.4 were chosen as a cut-off value to accept those loadings and hence meeting convergent validity criterion. The factor structure is shown in Table 3.

Based on the results in Table 3, it was noted that factor 1 (employee training) could be distinguished using four indicators with standardized factor loadings ranged between 0.69 and 0.77 , while factor 2 (employee empowerment) came into view through four indicators with standardized factor loadings ranged between 0.72 and 0.82 . Furthermore, the results indicated that the third factor of HRD practices (employee promotion) can be assessed using 4 indicators with standardized factor loadings ranged from 0.69 to 0.83 . Employee engagement and employee performance as outcomes of HRD practices were also emanated with four indicators for each, with standardized factor loadings no less than 0.66 . On that account, reliability as measured by composite reliability and Cronbach's alpha coefficients was supported for the reason that all values of CR along with alpha coefficients were greater than 0.7 (Al-Hawary, 2012). Convergent validity was also supported because all values of AVE were greater than 0.50 (Johari, Yahya, \& Omar, 2011). 
Table 3. Factor structure of questionnaire items

\begin{tabular}{|c|c|c|c|c|c|}
\hline Factor & Items & SFL & AVE & CR & $\alpha$ \\
\hline \multirow{4}{*}{ Employee training } & TRG1 & 0.721 & \multirow{4}{*}{0.527} & \multirow{4}{*}{0.816} & \multirow{4}{*}{0.823} \\
\hline & TRG2 & 0.725 & & & \\
\hline & TRG3 & 0.689 & & & \\
\hline & TRG4 & 0.766 & & & \\
\hline \multirow{4}{*}{ Employee empowerment } & EMP1 & 0.822 & \multirow{4}{*}{0.580} & \multirow{4}{*}{0.847} & \multirow{4}{*}{0.834} \\
\hline & EMP2 & 0.761 & & & \\
\hline & EMP3 & 0.741 & & & \\
\hline & EMP4 & 0.722 & & & \\
\hline \multirow{4}{*}{ Employee promotion } & PRO1 & 0.799 & \multirow{4}{*}{0.591} & \multirow{4}{*}{0.852} & \multirow{4}{*}{0.864} \\
\hline & PRO2 & 0.834 & & & \\
\hline & PRO3 & 0.689 & & & \\
\hline & PRO4 & 0.745 & & & \\
\hline \multirow{4}{*}{ Employee engagement } & ENG1 & 0.852 & \multirow{4}{*}{0.643} & \multirow{4}{*}{0.878} & \multirow{4}{*}{0.867} \\
\hline & ENG2 & 0.837 & & & \\
\hline & ENG3 & 0.772 & & & \\
\hline & ENG4 & 0.742 & & & \\
\hline \multirow{4}{*}{ Employee performance } & PER1 & 0.66 & \multirow{4}{*}{0.502} & \multirow{4}{*}{0.801} & \multirow{4}{*}{0.794} \\
\hline & PER2 & 0.72 & & & \\
\hline & PER3 & 0.76 & & & \\
\hline & PER4 & 0.69 & & & \\
\hline
\end{tabular}

\subsection{Goodness-of-fit model}

The measurement model shown in Figure 2 was assessed in terms of goodness-of-fit model using four indices, which are Chi-square/degree of freedom ratio (CMIN/DF), GFI (goodness-of-fit Index), CFI (comparative fit index), and RMSEA (Root mean square error of approximation). The results indicated that the values of these indices were acceptable, i.e., $\mathrm{CMIN} / \mathrm{DF}=2.66$, which is less than 3, GFI $=0.889$, which is close to $0.90, \mathrm{CFI}=0.91$, which is higher than 0.90 and RMSEA $=0.072$, which is less than 0.10 (Hoe, 2008; Hill, Rey, Marin, Sharp, Green, \& Pettit, 2015; Corrigan, Nieweglowski, \& Sayer, 2019).

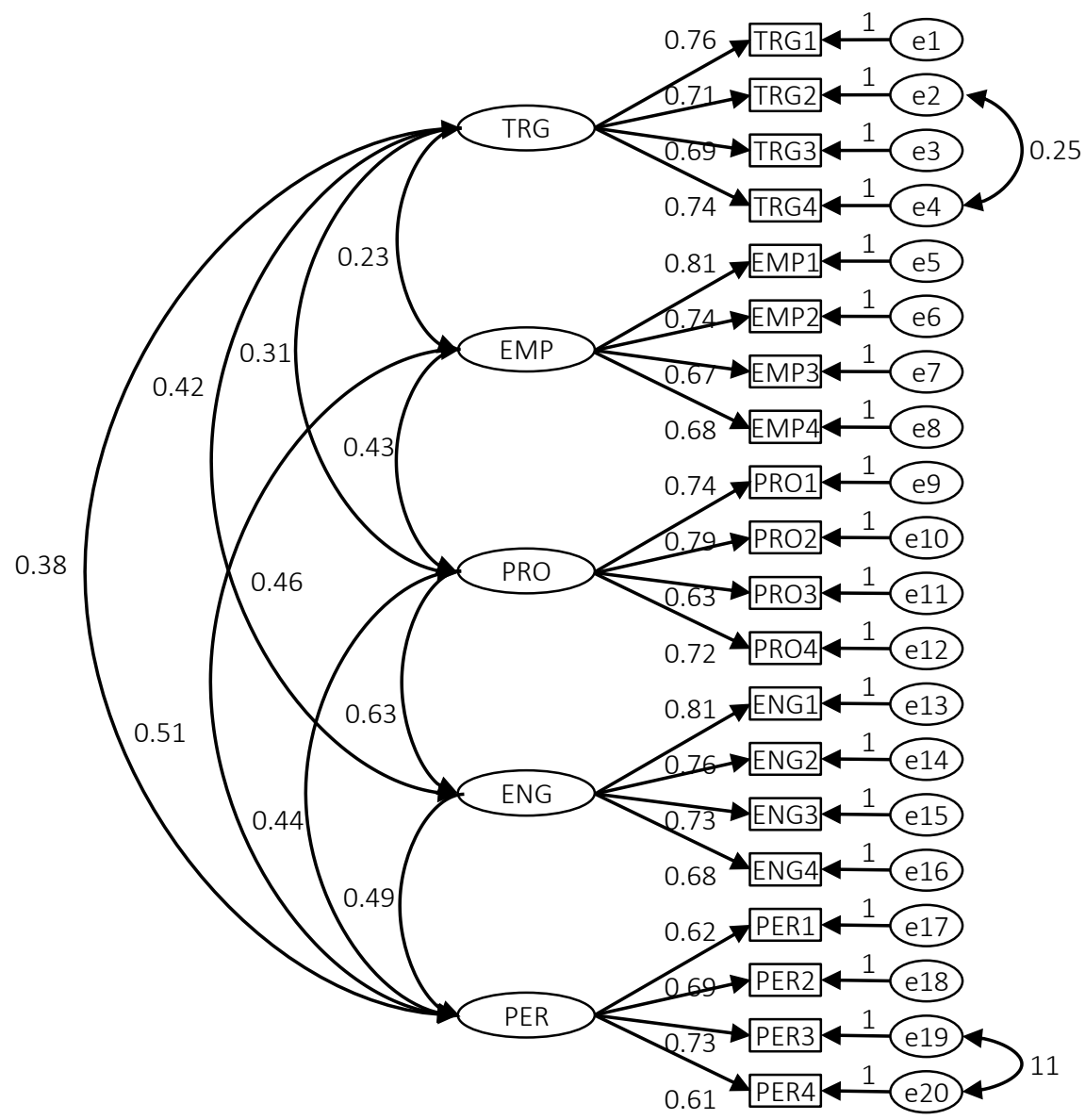

Figure 2. Research measurement model 


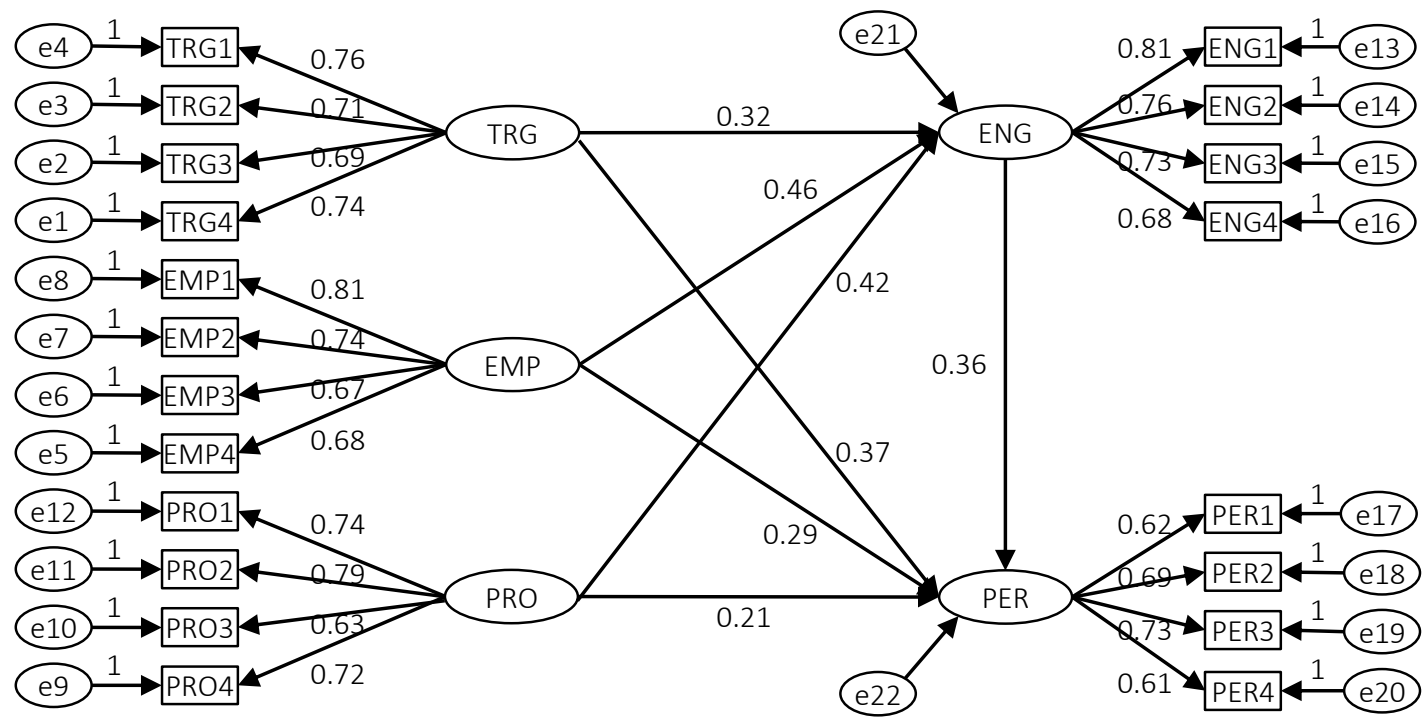

Figure 3. Structural research model

The structural research model constructed via structural equation modeling (SEM) with IBM AMOS version 22.0, as shown in Figure 3, illustrates that seven hypotheses were supported. The results are summarized in Table 4. However, different degrees of influence can be noted.

In terms of employee training (TRG), the results showed that the construct had significant effects on both employee engagement and employee performance $(\beta=0.32$ and $0.37, p<0.05)$, respectively. Therefore, $H 1$ and $H 2$ were accepted.

The results indicated that employee empowerment (EMP) has significant effects on employee engagement $(\beta=0.46, P<0.05)$ and employee performance $(\beta=0.29, p<0.05)$, which means that the current data supported $\mathrm{H} 2$ and $H 3$. Furthermore, the results demonstrated that employee promotion (PRO) exerted significant effects on employee engagement $(\beta=0.42, p<0.05)$ and employee performance $(\beta=0.21, p<0.05)$, which confirmed that $\mathrm{H} 3$ and $\mathrm{H} 4$ were true. Finally, employee en- gagement has emerged as a significant predictor of employee performance $(\beta=0.36, p<0.05)$, hence, H7 was accepted.

\section{DISCUSSION}

Similar results were found in prior works. Collecting data from participants in numerous sectors in Pakistan, Nawaz et al. (2014) showed significant effects of employee training and development on employee engagement. According to Chandani, Mehta, Mall, and Khokhar (2016), employee training is one of the most significant factors affecting employee engagement. Akhtar, Nawaz, Mahmood, and Shahid (2016) underlined significant effects of high performance human resource practices, i.e., employee training, employee empowerment, and employee rewards, on employee engagement and employee performance. Their results confirmed that employee engagement played a significant role as a mediating variable between high-performance human resource practic-

Table 4. Results of hypotheses testing

\begin{tabular}{|c|c|c|c|c|c|c|}
\hline \multirow[b]{2}{*}{$H 1$} & \multicolumn{3}{|c|}{ Paths between variables } & \multirow{2}{*}{$\frac{\boldsymbol{\beta}}{0.32}$} & \multirow{2}{*}{$\frac{\boldsymbol{t} \text {-value }}{11.32}$} & \multirow{2}{*}{$\frac{p \text {-value }}{0.000}$} \\
\hline & Employee training & $\rightarrow$ & Employee engagement & & & \\
\hline $\mathrm{H} 2$ & Employee training & $\rightarrow$ & Employee performance & 0.37 & 10.29 & 0.000 \\
\hline $\mathrm{H3}$ & Employee empowerment & $\rightarrow$ & Employee engagement & 0.46 & 16.13 & 0.001 \\
\hline H4 & Employee empowerment & $\rightarrow$ & Employee performance & 0.29 & 14.22 & 0.002 \\
\hline $\mathrm{H} 5$ & Employee promotion & $\rightarrow$ & Employee engagement & 0.42 & 15.04 & 0.000 \\
\hline H6 & Employee promotion & $\rightarrow$ & Employee performance & 0.21 & 8.16 & 0.031 \\
\hline$H 7$ & Employee engagement & $\rightarrow$ & Employee performance & 0.36 & 13.22 & 0.002 \\
\hline
\end{tabular}


es and employee performance. For Bowra, Sharif, Saeed, and Niazi (2012), employee performance appraisal and employee promotion had significant effects on employee performance. Moreover, Shabbir (2014) pointed out a significant effect of employee promotion on employee performance. It was revealed that employee training is positively related to his or her performance. Using a sample of middle and operational management levels in small organizations in India, Anitha (2014) found a significant impact of employee engagement on employee performance.

Training is one of the most important HRD practices. It can be viewed through the individual and the organizational lenses. The individual lens, in line with the theory of social identity (Asfaw, Argaw, \& Bayissa, 2015) refers to the individual's view as the motivation behind his or her behavior towards the social system as a whole. Therefore, the employee who seeks to develop his or her career should acquire more skills. Human capital theory, in the same line, indicates that employee characteristics, such as employee education level and training, have an impact on employee productivity (Yamoah, 2014). On the contrary, employee empowerment may be psychological or behavioral (Boudrias, Gaudreau, Savoie, \& Morin, 2009). Perhaps, the first type is prevalent in the current study, where empowerment was associated with employee engagement more than with employee performance because the employee believes that he or she can influence the work and the work environment. As for the relationship between employee promotion and performance, the employee believes that the promotion was due to good performance, and therefore no need to improve performance because he or she believes that he or she has already met the performance requirements.

In a study on employee training as HRD practices and technological change in Singapore by OsmanGani and Jacobs (2005), employee training as an important HRD practice has been studied by introducing the methods used to implement the training programs. Examples include practical work training on the job, computer-based training, and training using workshops and seminars, and simulation-based training. According to Sparkes and Miyake (2000), both employee off-the-job and on-the-job training make up two principles of HRD in knowledge transfer. Brown and Latham (2000) showed that not all types of training lead to improved performance; for example, they concluded that self-instruction training did not improve employee performance. The present study did not include the verification of the role of training methods, so researchers are advised to conduct the studies using such methods. Moreover, this study examines five dimensions of HRD practices; therefore, it was recommended that more dimensions of HRD should be used in future studies.

\section{CONCLUSION}

This study aimed to explore the impact of human resource development practices on employee engagement and employee performance. Out of HRD practices identified in the literature, three were chosen for this study: employee training, employee empowerment, and employee promotion. Furthermore, the study aimed at investigating the impact of employee engagement on employee performance.

The results showed that the seven hypotheses were supported. And all of the practices (employee training, employee empowerment, and employee promotion) were positively related to both employee engagement and employee performance.

According to the hypotheses $(H 1, H 2$, and $H 3)$ employee empowerment had the highest influence on employee engagement, followed by employee promotion and employee training.

For the hypotheses ( $H 4, H 5$, and $H 6$ ) Employee empowerment was also the best in terms of its effect on employee performance, followed by employee training and employee promotion. These results asserted that HRD practices are different in their impacts on employee engagement and employee performance. 
Some affect employee engagement more than others and some affect employee performance more than others. This means that an organization seeks to achieve employee engagement should focus primarily on employee empowerment and then on employee promotion. However, if the organization's goal is to improve employee performance, it should focus on employee training in the first place.

Finally, the last hypothesis (H7) shows that employee engagement enhance employee performance. So Organizations need to give emphasis on improving the employee engagement, by designing HRD practices to ensure positive outcomes.

\section{REFERENCES}

1. Aguta, U., \& Balcioglu, H. (2015). The impact of human resource management practices on organizational performance: a case of private banks in North Cyprus. International Journal of Business and Social Science, 6(6), 251-268. Retrieved from http:// ijbssnet.com/journals/Vol_6_ No_6_June_2015/24.pdf

2. Akhtar, A., Nawaz, M., Mahmood, Z., \& Shahid, M. (2016). Impact of high performance work practices on employees' performance in Pakistan: Mediating role of employee engagement. Pakistan Journal of Commerce and Social Sciences (PJCSS), 10(3), 708-724. Retrieved from http://jespk.net/ publications/332.pdf

3. Aleem, M., \& Ur Rahman, M. (2018). HRM practices and their impacts on the perceived performance of SME's operating in Karachi. Pakistan Business Review, 20(2), 390-402. Retrieved from https://journals.iobmresearch.com/index.php/PBR/article/view/802

4. Al-Hawary, S. (2012). Health care services quality at private hospitals, from patients perspective: A comparative study between Jordan and Saudi Arabia. African Journal of Business Management, 6(22), 6516-6529. Retrieved from https:// www.semanticscholar.org/paper/ Health-care-services-quality-atprivate-hospitals\%2C-Al-Hawary/ 32f23536612ed04764eb69d42a2b6 b948fb7e565

5. Al-Hawary, S., \& Al-Smeran, W. (2016). Impact of electronic service quality on customers satisfaction of Islamic banks in Jordan. International Journal of
Academic Research in Accounting,

Finance and Management Sciences,

7(1), 170-188. http://dx.doi.

org/10.6007/ijarafms/v7-i1/2613

6. Al-Hawary, S. I., Al-Qudah, K. A., Abutayeh, P. M., Abutayeh, S. M., \& Al-Zyadat, D. Y. (2013). The impact of internal marketing on employee's job satisfaction of commercial banks in Jordan. Interdisciplinary Journal of Contemporary Research in Business, 4(9), 811-826. Retrieved from https://www.researchgate. net/publication/328881053_The_ impact_of_internal_marketing_ on_employee's_job_satisfaction_ of_commercial_banks_in_Jordan/ link/5be96911a6fdcc3a8dd0407e/ download

7. Ali, M., \& Ahmad, N. (2017). Impact of pay promotion and recognition on job satisfaction: A study on banking sector employees Karachi. Global Management Journal for Academic \& Corporate Studies, 7(2), 131-141. Retrieved from https://gmjacs.bahria.edu. pk/wp-content/uploads/2018/01/ paper-no-10.pdf

8. Alshery, W., Ahmad, F., \& Al-Swidi, A. (2015). The moderating effect of role ambiguity on the relationship of job satisfaction, training and leadership with employee performance. International Journal of Business Administration, 6(2), 30-41. http://dx.doi.org/10.5430/ ijba.v6n2p30

9. Amirthaiyan, S., \& Victor, S. (2016). An assessment of human resource development mechanisms with reference to textile companies in Tiruppur District of Tamilnadu. Asian Journal of Research in Social Sciences and Humanities, 6(7), 1211-1224. http://dx.doi.org/10.5958/22497315.2016 .00506 .2

10. Anitha, J. (2014). Determinants of employee engagement and their impact on employee performance. International Journal of Productivity and Performance Management, 63(3), 308-323. http://dx.doi. org/10.1108/ijppm-01-2013-0008

11. Archana, P., \& Krishna, B. (2016). A critical study of human resource development practices in selected Indian industries. ITIHAS the Journal of Indian Management, 6(1), 9-16. Retrieved from http://www. indianjournals.com/ijor.aspx?targe $\mathrm{t}=\mathrm{ijor}: \mathrm{ijim} \&$ volume $=6 \&$ issue $=1 \& \mathrm{a}$ rticle $=002$

12. Asfaw, A., Argaw, M., \& Bayissa, L. (2015). The impact of training and development on employee performance and effectiveness: A case study of District Five Administration Office, Bole Sub-City, Addis Ababa, Ethiopia. Journal of Human Resource and Sustainability Studies, 3(04), 188202. http://dx.doi.org/10.4236/ jhrss.2015.34025

13. Bacon, D., Sauer, P., \& Young, M. (1995). Composite reliability in structural equations modeling. Educational and Psychological Measurement, 55(3), 394-406. Retrieved from https://pascal-francis.inist.fr/vibad/index.php?action= getRecordDetail\&idt=3536448

14. Boudrias, J., Gaudreau, P., Savoie, A., \& Morin, A. J. (2009). Employee empowerment: From managerial practices to employees' behavioral empowerment. Leadership \& Organization Development Journal, 30(7), 625-638. https://doi. org/10.1108/01437730910991646 
15. Bowra, Z., Sharif, B., Saeed, A., \& Niazi, M. (2012). Impact of human resource practices on employee perceived performance in banking sector of Pakistan. African Journal of Business Management, 6(1), 323332. Retrieved from https://pdfs. semanticscholar.org/be4d/34fcb9 5f2995bdd4991f0883dac09fb29b 4a.pdf

16. Brown, T., \& Latham, G. (2000). The effects of goal setting and self-instruction training on the performance of unionized employees. Relations Industrielles/Industrial Relations, 55(1), 80-95. http://dx.doi. org/10.7202/051292ar

17. Busari, A., Mughal, Y., Khan, S., Rasool, S., \& Kiyani, A. (2017). Analytical cognitive style moderation on promotion and turnover intention. Journal of Management Development, 36(3), 438-464. http://dx.doi.org/10.1108/ jmd-12-2015-0184

18. Chandani, A., Mehta, M., Mall, A., \& Khokhar, V. (2016). Employee engagement: A review paper on factors affecting employee engagement. Indian Journal of Science and Technology, 9(15), 1-7. http://dx.doi.org/10.17485/ ijst/2016/v9i15/92145

19. Chen, Z., Tsui, A., \& Farh, J. (2002). Loyalty to supervisor vs. organizational commitment: Relationships to employee performance in China. Journal of Occupational and Organizational Psychology, 75(3), 339-356. http://dx.doi. org/10.1348/096317902320369749

20. Corrigan, P., Nieweglowski, K., \& Sayer, J. (2019). Self-stigma and the mediating impact of the "why try" effect on depression. Journal of Community Psychology, 47(3), 698-705. http://dx.doi.org/10.1002/ jcop.22144

21. Etikan, I., Musa, S., \& Alkassim, R. (2016). Comparison of convenience sampling and purposive sampling. American Journal of Theoretical and Applied Statistics, 5(1), 1-4. http://dx.doi.org/10.11648/j. ajtas.20160501.11

22. Fletcher, L. (2019). How can personal development lead to increased engagement? The roles of meaningfulness and perceived line manager relations. The International Journal of Human Resource Management, 30(7), 12031226. http://dx.doi.org/10.1080/095 85192.2016.1184177

23. Hidayat, R., \& Budiatma, J. (2018). Education and job training on employee performance. International Journal of Social Sciences and Humanities, 2(1), 171181. http://dx.doi.org/10.29332/ ijssh.v2n1.140

24. Hill, R., Rey, Y., Marin, C., Sharp, C., Green, K., \& Pettit, J. (2015). Evaluating the Interpersonal Needs Questionnaire: Comparison of the reliability, factor structure, and predictive validity across five versions. Suicide and LifeThreatening Behavior, 45(3), 302-314. https://doi.org/10.1111/ sltb.12129

25. Hoe, S. L. (2008). Issues and procedures in adopting structural equation modeling technique. Journal of Applied Quantitative Methods, 3(1), 76-83. Retrieved from http://jaqm.ro/issues/volume3,issue-1/pdfs/hoe.pdf

26. Idris, A., See, D., \& Coughlan, P. (2018). Employee empowerment and job satisfaction in urban Malaysia: Connecting the dots with context and organizational change management. Journal of Organizational Change Management, 31(3), 697-711. http:// dx.doi.org/10.1108/jocm-04-20170155

27. Jain, V. (2014). Performance appraisal as a sub-system of HRD: A case study. IOSR Journal of Business and Management (IOSRJBM), 16(1), 26-34. http://dx.doi. org/10.9790/487x-16172634

28. Johari, J., Yahya, K., \& Omar, A. (2011). The construct validity of organizational structure scale: Evidence from Malaysia. World Journal of Management, 3(2), 131-152. Retrieved from https:// pdfs.semanticscholar.org/28bb/ e74a23d029096db325a52a567bbla94a19bb.pdf?_ga=2.197322095.1563226635.1581081516-726205763.1581081516

29. Jose, G., \& Mampilly, S. (2012). Satisfaction with HR practices and employee engagement: A social exchange perspective. Journal of Economics and Behavioral Studies, 4(7), 423-430. Retrieved from https://doi.org/10.22610/jebs. v4i7.343

30. Kahn, W. (1990). Psychological conditions of personal engagement and disengagement at work. Academy of Management Journal, 33(4), 692-724. http://dx.doi. org/10.5465/256287

31. Mozael, B. (2015). Impact of training and development programs on employee performance. International Journal of Scientific and Research Publications, 5(11), 37-42. Retrieved from http://www.ijsrp.org/researchpaper-1115/ijsrp-p4708.pdf

32. Mugizi, W. (2019). Human resource development practices and organizational commitment of teacher in government aided secondary schools in Wakiso District, Uganda. International Journal of Education and Social Science Research, 2(2), 68-85. Retrieved from https://www.researchgate. net/publication/331801800_ HUMAN_RESOURCE_ DEVELOPMENT_PRACTICES_ AND_ORGANISATIONAL_COMMITMENT_OF_TEACHERS_IN_ GOVERNMENT_AIDED_SECONDARY_SCHOOLS_IN_WAKISO_DISTRICT_UGANDA

33. Nawaz, M., Hassan, M., Hassan, S., Shaukat, S., \& Asadullah, M. (2014). Impact of employee training and empowerment on employee creativity through employee engagement: Empirical evidence from the manufacturing sector of Pakistan. Middle-East Journal of Scientific Research, 19(4), 593-601. Retrieved from https://pdfs.semanticscholar.org/c024/6f57d1eb3c69df 1cedf84030ca60742fc62d.pdf

34. Njagi, L. (2012). Relationship between social capital and employee promotion. International Journal of Business \& Commerce, 1(10), 1-13. Retrieved from http:// www.ijbcnet.com/1-10/IJBC-121913.pdf

35. Osman-Gani, A., \& Jacobs, R (2005). Technological change and 
human resource development practices in Asia: A study of Singapore-based companies. International Journal of Training and Development, 9(4), 271-280. http://dx.doi.org/10.1111/j.14682419.2005.00236.x

36. Otoo, F. (2019). Human resource development (HRD) practices and banking industry effectiveness: The mediating role of employee competencies. European Journal of Training and Development, 43(3/4), 250-271. http://dx.doi.org/10.1108/ ejtd-07-2018-0068

37. Otoo, F., Otoo, E., Abledu, G., \& Bhardwaj, A. (2019). Impact of human resource development (HRD) practices on pharmaceutical industry's performance: The mediating role of employee performance. European Journal of Training and Development, 43(1/2), 188-210. https://doi.org/10.1108/ ejtd-09-2018-0096

38. Paposa, K., \& Kumar, Y. (2019). Impact of training and development practices on job satisfaction: A study on faculty members of technical education institutes. Management and Labour Studies, 44(3), 248-262. http://dx.doi. org/10.1177/0258042x19851649

39. Peterson, S., Luthans, F., Avolio, B., Walumbwa, F., \& Zhang, Z. (2011). Psychological capital and employee performance: A latent growth modeling approach. Personnel Psychology, 64(2), 427-450. http:// dx.doi.org/10.1111/j.17446570.2011.01215.x

40. Potnuru, R., Sahoo, C., \& Sharma, R. (2019). Team building, employee empowerment and employee competencies: Moderating role of organizational learning culture. European Journal of Training and Development, 43(1/2), 39-60. http:// dx.doi.org/10.1108/ejtd-08-20180086

41. Raubenheimer, J. (2004). An item selection procedure to maximize scale reliability and validity. $S A$ Journal of Industrial Psychology, 30(4), 59-64. http://dx.doi. org/10.4102/sajip.v30i4.168

42. Saks, A. (2006). Antecedents and consequences of employee engagement. Journal of Managerial Psychology, 21(6),
600-619. http://dx.doi. org/10.1108/02683940610690169

43. Sattar, T., Ahmad, K., \& Hassan, S. (2015). Role of human resource practices in employee performance and job satisfaction with mediating effect of employee engagement. Pakistan Economic and Social Review, 53(1), 81-96. Retrieved from http://pu.edu.pk/images/ journal/pesr/PDF-FILES/4\%20 SATTAR\%20Role\%20of\%20Human_v53_1_15.pdf

44. Schaufeli, W., Salanova, M., González-Romá, V., \& Bakker, A. (2002). The measurement of engagement and burnout: A two sample confirmatory factor analytic approach. Journal of Happiness Studies, 3(1), 71-92. Retrieved from http://www.jwalkonline.org/ docs/Grad\%20Classes/Fall\%2007/ Org\%20Develop/presentation/ARTICLES/measure $\% 20$ engage $\% 20$ and\%20burnout.pdf

45. Shabbir, M. (2014). The impact of human resource practices on employee perceived performance in pharmaceutical sector of Pakistan. African Journal of Business Management, 8(15), 626632. http://dx.doi.org/10.5897/ ajbm2013.7295

46. Shuck, B., Twyford, D., Reio Jr, T., \& Shuck, A. (2014). Human resource development practices and employee engagement: Examining the connection with employee turnover intentions. Human Resource Development Quarterly, 25(2), 239-270. http://dx.doi. org/10.1002/hrdq.21190

47. Smith, E., Callan, V., Tuck, J., \& Smith, A. (2019). Employer training in Australia: current practices and concerns. International Journal of Training and Development, 23(2), 169-183. http://dx.doi.org/10.1111/ ijtd.12152

48. Sparkes, J., \& Miyake, M. (2000). Knowledge transfer and human resource development practices: Japanese firms in Brazil and Mexico. International Business Review, 9(5), 599-612. http://dx.doi.org/10.1016/ s0969-5931(00)00021-4

49. Sweis, R. J., Al-Mansour, A., Tarawneh, M. Y., \& Al-Dweik, G. (2013). The impact of total quality management practices on employee empowerment in the healthcare sector in Saudi Arabia: A study of King Khalid Hospital. International Journal of Productivity and Quality Management, 12(3), 271-286. http://dx.doi.org/10.1504/ ijpqm.2013.056149

50. Tahsildari, A., \& Shahnaei, S. (2015). Enhancing organizational effectiveness by performance appraisal, training, employee participation, and job definition. European Journal of Business and Management, 7(12), 56-63. Retrieved from http://citeseerx.ist. psu.edu/viewdoc/download?doi $=10.1 \cdot 1.735 .1222 \& r e p=r e p 1 \& t y p$ $\mathrm{e}=\mathrm{pdf}$

51. Uraon, R., \& Gupta, M. (2019). Do HRD practices affect perceived market performance through operational performance? Evidence from software industry. International Journal of Productivity and Performance Management, 69(1), 85-108. http://dx.doi. org/10.1108/ijppm-06-2018-0207

52. Yamoah, E. (2014). The link between human resource capacity building and job performance. International Journal of Human Resource Studies, 4(3), 139. http:// dx.doi.org/10.5296/ijhrs.v4i3.5938 